\begin{tabular}{|c|c|c|}
\hline $\mathbf{u} p f$. & $\begin{array}{l}\text { Universitat } \\
\text { Pompeu Fabra } \\
\text { Barcelona }\end{array}$ & $\begin{array}{l}\text { Department } \\
\text { of Economics and Busine }\end{array}$ \\
\hline
\end{tabular}

Economics Working Paper Series

Working Paper No. 1695

\title{
Privatizing public registries: a comparative analysis of organizational options
}

\author{
Benito Arruñada
}

February 2020 


\title{
Privatizing Public Registries: \\ A Comparative Analysis of Organizational Options
}

\author{
Benito Arruñada 1
}

\begin{abstract}
With a focus on public registries, this article analyzes the organization of public registries comparing five organizational forms: (1) the bureaucratic expense centers used to provide privately valuable services in the welfare state; (2) the internal markets introduced to reform them and the hybrid solutions that have been used by the liberal state since the $19^{\text {th }}$ century to provide such privately valuable services, including (3) revenue centers based on user fees, (4) franchised systems in which professional civil servants are in addition paid with the profit of an office, and (5) the contemporary variant in which the Government contracts out the provision of the whole service to a private firm. This comparison suggests that market forces may play a better role in organizing public registries when they are limited to a few variables, which makes stronger incentives possible and, at the same time, reduces the need for extensive planning and supervisory staff.
\end{abstract}

JEL codes: H11, H42, H51, H52, K23

Keywords: internal markets, competition, bureaucracy, registries, welfare, incentives, user fees, user choice, privatization

1 Pompeu Fabra University and Barcelona GSE. E-mail: benito.arrunada@upf.edu. This work is a revised version of the paper presented at the IPRA-CINDER XXI World Registry Law Congress, Cartagena de Indias, May 4, 2018. It has greatly benefitted from exchanges with Jürgen Backhaus, José Manuel Freire, Fernando Méndez, Stephen Hansen, Cándido Paz-Ares, Yannick Perez, Carlos Rodríguez Braun, Jérôme Sgard, Barry Weingast and participants at the EIU Workshop on "Legal Order, The State and Economic Development," the CUNEF Workshop on "The Economics of Institutions and Organizations," and the IPRACINDER $21^{\text {st }}$ International Conference, as well as the support of the Spanish Government through grant ECO2017-85763-R and the Severo Ochoa Program for Centers of Excellence in R\&D (SEV-2015-0563). Usual disclaimers apply. 


\section{Introduction: The organization of public services}

Most public services are now organized as what the literature of Managerial Accounting calls “discretionary expense centers” (Kaplan and Atkinson 1989:531-33), so that each supplying unit receives a budget with which it has to provide services, usually unpaid, to other departments or end users. When the performance of such units is evaluated, if ever, this is usually based on subjective judgment and grossly incomplete indicators. Many of the decisions on what to produce, for whom and even how are usually centralized or subject to detailed decision-making procedures.

In business firms, the use of expense centers is usually limited to areas in which it is difficult to measure their activities, in terms not only of efficiency but also of effectiveness, and in which it is not only difficult to link the resources used with the services rendered but also to define and evaluate the degree to which the objectives are achieved. Such characteristics can be found, especially, in central departments and in the actual general management of firms. The extent to which it is difficult to make such measurements usually depends on the type of resources and technology used and the services provided. The resources may be difficult to evaluate because of their high human capital content and because the costs are shared amongst or can be allocated to a wide range of users and products. In addition, many of the production processes may present a low degree of standardization and provide a wide range of services to other departments within the same organization or to external customers. Finally, many services are of an intangible nature so, though their quality is very important, it is difficult to evaluate because subjective elements 
are involved. It is often the case that only the users are aware of the quality and this knowledge is difficult to pass on to the person who has the authority to take corrective action. In the worst possible case, not even the users are aware of the real quality. This is especially so when activities are intensive in human capital so their quality can only be evaluated by qualified personnel.

In public services, technology also limits the possibility of measurement because many activities present the same characteristics. This is especially the case in the production of what economists call public goods: those for which there is no "rivalry" (i.e., use by one user does not reduce availability to others) and “exclusion” is impossible (i.e., users cannot be excluded from use). They are characteristic of services defining the "liberal state", such as national defense or the police.

It is much less difficult to measure the services that constitute the core of the "welfare state," such as health, education or pensions and other types of social insurance. These are privately valuable services in which it would be possible to exclude people from consuming them (except for their "external effects", which are of varying importance and could be handled in many other ways apart from direct state provision). However, in spite of their private nature, they have often been provided free of charge by state agencies which have been financed by taxes unrelated to consumption.

Moreover, in many cases it was also decided that discretionary expense centers should be responsible for their own organization, with a budget being allocated to the civil servant or the department rendering the service without paying them according to performance. These two patterns are in contrast to the system usually adopted previously for public services having private utility, such as those provided by public registries. Especially in the services that were re-organized during the liberal state of the $19^{\text {th }}$ century (justice, registers, 
pharmacies and even, to some extent, education), activities were highly regulated but explicit fees were charged to users, and high-powered incentives were offered to suppliers. In some cases, professionals were even treated as public franchisees and compensated with the residual profit of their unit, after paying for any other resources for which they were responsible.

Recent reforms in public services, which have for decades been provided free of charge by expense centers, aim to recreate a market, introducing both some form of user choice and suppliers' incentives, in particular increasing competition between suppliers. It is not a question of "inter-organizational” competition between different organizations but rather of the "intra-organizational" competition among the divisions or departments of a single public organization. Such intra-organizational competition within the Administration is similar to that which often exists in large corporations. The problems it creates are not completely new but they are more complex (Arrow 1970:229). The large multi-divisional corporations have extensive experience in dealing with it and have developed many formulae for this purpose. Like the Public Administration, such corporations are constantly suffering from the tendency for administrative units to grow excessively and to provide services inefficiently to the other divisions. At root, such failures can only be remedied by changing the incentives of the two parties. Firstly, those of the internal users, making them pay for the services they acquire from the expense center and, secondly, those of the internal suppliers, taking from them their monopoly for the provision of such services. Sometimes, an attempt is made to create a sort of "internal market" within the firm. The general management of the organization then has to act as regulator of the competition that arises among its internal divisions.

This work first examines the general difficulties arising when elements of this type of internal competition are introduced in Public Administration and suggests that the role of 
market forces may be more productive if limited to a few variables. This seems to make stronger incentives possible while reducing the need for extensive planning and supervisory staff. The argument is applied to the reform and privatization of public registries, to the extent that some of these efforts in fact only modify the legal status of registries within the organization of the state without providing strong incentives but expanding the regulatory bureaucracy charged with managing the new system.

The rest of the article proceeds as follows. Section 2 describes how public services commonly organized as budgetary or 'discretionary expense' centers, which do not charge users, tend to be too large and inefficient. Section 3 examines the possibilities and difficulties arising from the transformation of such expense centers into units that are to some extent subject to market forces, with users facing opportunity costs and suppliers being subject to competitive pressure. Section 4 analyzes solutions that have been used since the inception of the liberal state for organizing legal and judicial services in continental Europe, focusing on the case of Spain. These solutions involve strong incentives with little management, hinting that, instead of spending huge amounts of money on developing comprehensive internal markets with large management staffs but weak incentives, effective solutions may instead be based on relatively automatic management of strong incentives based on a few key variables of performance. Section 5 summarizes the traditional organization of public registries, mainly as revenue centers and franchised units, and compares it with recent privatization efforts. Section 6 concludes. 


\section{The pathology of bureaucracy}

Whether located in the public or the private sector, expense centers tend to be chronically inclined towards oversizing and overspending (Niskanen 1968, 1971). This is partly the result of circumstances associated with the incentives of producers and users and with the lack of information available to the person in charge of controlling the activity.

With regard to incentives, it usually happens that the remuneration, power and promotion prospects of those responsible for the expense center-and, in general, for all those working within it-increase when the center's budget increases, which means that they all have a common interest in enlarging it. Moreover, when users do not pay for the goods and services they acquire or when what they do pay does not vary in line with their level of consumption, most of them tend to demand them beyond the optimum level, that is, the level at which the cost would be the same as the marginal value for the organization or group. Obviously, this possibility is greater for goods or services that show positive utility.

The person in charge of allocating and controlling the use of resources finds it difficult to determine the budget for expense centers as there is no information indicating what is valuable or not in the consumption of the services rendered by the centers. In addition, even if it were possible to establish the budget for each expense center at its optimal level, it would still be difficult to evaluate the way in which the budgets are spent. For example, neither a deficit nor a surplus in an expense center indicates either wastage or efficiency because the center's products are not measured. And the managers of expense centers are interested in maintaining the informational disadvantage of the person responsible for the budget. They will therefore resist any policy aiming to measure the amount or quality of the services. For the same reason, they will tend to conceal the availability of idle resources and are unlikely to 
present a budget surplus as this might be interpreted as meaning they have excess resources. They are more likely to spend all available resources, even on purchases offering limited utility. In a similar way, users will tend to exaggerate the value of what they consume.

Because of these information asymmetries, the most that can be expected is that the problem will be contained within sustainable limits, using palliatives of doubtful efficiency, such as supervision and budgetary reviews. An incremental procedure is often adopted, focusing not on volume or resources but only on any new budget allocations or cutbacks. In practice, attempts to draw up new budgets starting from zero and reviewing all expenditure are both costly and inefficient. Since expense centers have this tendency to overspend, they often find their budgets cut when the organization they belong to is going through hard times (Neuman 1975), whether it is a company, a town council or a government. Such cutbacks entail certain problems. It is often not known in which areas a reduction of expenditure would be most effective or, even if this is known, it may be impossible to apply cutbacks in one area and not another. Crises often lead to overall cutbacks, perhaps to contain the costs generated by the actual budgetary battle, when their effects are anyway likely to be temporary. The problem is likely to reappear soon, because cutbacks do not solve the root of the problem which lies in the interests of the centers and their clients and is aggravated by the information difficulties suffered by the person responsible for the budgetary allocation. It may even occur that the cutbacks do not reduce expenditure as they come up against all sorts of restrictions and defense strategies on the part of those affected. The threat of dumping dead bodies in the manager's office has been used so often that it features as a category in some texts on hospital sociology.

Admittedly, this description simplifies the conduct of expense centers at least in two dimensions. First, it describes privately valuable services better than purely public services. 
The theory therefore tallies with the argument whereby bureaucracies tend to provide too many private goods and too few public goods (Breton 1974). Second, bureaucrats often focus more on leisure than on growth (Peacock, 1983), and may aim to increase not the whole budget available but only those items which provide greater personal utility (Dunleavy 1985, 1991). Moreover, it assumes a degree of autonomy that only exists in certain administrations, especially in the USA (Peters 1996:26-27). However, this criticism pays greater attention to formal autonomy and its short-term effects than to the actual autonomy which creates the information asymmetry and, especially, the implicit collusion between suppliers and users, as well as the long-term effects which are similar, irrespective of the degree of formal autonomy. Certainly, many expense centers in public administration have little formal discretion. However, they have an information advantage that grants them considerable informal discretion for allocating resources internally and manipulating central decisions on resource allocation and choice of procedure. For the more professional services, formal regulation of production processes is usually very detailed but officials still have considerable discretion over their own quality and productivity.

\section{Internal competition as a solution to the problems of bureaucracy}

As an alternative to such palliative treatments, a more radical way of dealing with expense centers is to change participants' incentives, so that users incur some cost when they demand services and suppliers are paid for their performance. Ideally, this should provide an automatic control of quantity and quality of service, eliminating surplus demand and utilizing the information of users and suppliers on utility and cost, without any need to transfer this 
information to the unit responsible for the budget. Ideally, the system should play the informational role of the market (Hayek 1945).

\subsection{Users and suppliers' incentives}

The most basic requirement for motivating users so that their decisions help to achieve better allocation of resources is that their consumption of the service should incur a positive opportunity cost. They will then reveal their evaluation of the service and, providing other conditions are met, the supplier will be encouraged by the competition. ${ }^{2}$

There are many possibilities for reform. The most obvious way of generating an opportunity cost is to charge a real price for internal transactions. In addition, the payment of a real price usually provides a powerful incentive. However, instead of real prices, nominal prices are often used with the corresponding accounting entries in the accounts of suppliers. In the public sector, such nominal charges usually take the form of vouchers with which users can purchase services from specific public or private suppliers. The use of nominal prices reduces user motivation but will not necessarily destroy it altogether, provided that such nominal prices reflect real opportunity costs, as when users are able to obtain other services with these resources or, at least, the same services but from different suppliers.

Under any circumstances, in order to be an efficient control mechanism, the supplier should be in a situation of competition or, at least, users should be able to use their resources for other purposes. If, for example, each department in a university is allocated 100,000 USD 
to be spent only on photocopying, such departments would not have much motivation for controlling a single internal supplier. If, however, they are allowed to spend this amount on other things, they would implicitly be controlling the supplier by moving their demand elsewhere even though, by so doing, they would be complicating the budget problem.

Regarding suppliers, the most important general options are in theory represented by the different possibilities of divisional organization of expense centers in the form of cost centers, revenue centers, profit centers and investment centers and even franchises, the latter being a hybrid formula between organization and market. As decisions are increasingly delegated to the center in question, the performance indicator will have to be increasingly global (Kaplan and Atkinson 1989:529-33). This means that the person in charge of a cost center usually decides how resources should be used but not how many should be produced nor their quality, and this person is evaluated by some sort of indicator of production cost. In revenue centers, those in charge are evaluated by turnover or revenue, and a decision is freely taken on the amounts sold or the selling price, but not on both variables. A profit center manager must maximize some type of divisional accounting profit and is usually free to decide not only how resources should be used but also about production, quality and product prices. In investment centers, in addition to the attributes of profit centers, there is also freedom and responsibility regarding the use of larger amounts of resources as these include the capital used by the center. Finally, a franchise provides a hybrid solution in which the franchisee owns a large proportion of the assets and is paid from the profits of the local outlet.

2 It is debatable if paying internal prices without any freedom of choice regarding either the amount of services or their price also generates incentives for control, as argued by Zimmerman (1979). 
The remuneration of whoever is in charge of such a center has to be linked to some sort of performance indicator so that they show interest in using their resources optimally. For example, the director of a school that has managed to raise demand for places or to improve students' academic performance could be rewarded with an annual bonus or promotion. And vice versa, if the performance indicators drop, not only would the director see a drop in income and fewer chances of promotion but the school might lose its independence or a substitute director might be called in to turn it around.

\subsection{The nature and costs of control}

In theory, there are many possibilities for this type of transformation of expense centers but the essential characteristics are defined by just two variables: freedom and responsibility. Freedom refers to the degree of discretion that participants are given in their decisions. Responsibility refers to the mechanisms used to evaluate and compensate their performance. Together, these give rise to a wide range of possibilities from which reformers must choose (Table 1). ${ }^{3}$ Freedom is introduced by redistributing decision rights: decisions that were previously centralized are delegated to users and suppliers. Responsibility, which before hinged mainly on hierarchical or vertical control that aimed to evaluate compliance (rather than performance), starts to be based on some degree of horizontal and mutual control: that

3 This analysis of the elements of organizational control is based on Arrow (1964) and, especially, Jensen and Meckling (1995). Arrow formulates organizational control as the interaction of operating rules and enforcement. Jensen and Meckling express these operating rules as the allocation of decision rights (freedom) and distinguish two phases in enforcement (responsibility)—evaluation and compensation for performance. 
exerted by users on suppliers through their purchase decisions and by suppliers on users through their pricing policy.

Table 1. Design dimensions: participants’ freedom and responsibility

\begin{tabular}{|c|c|c|}
\hline & $\begin{array}{c}\text { Freedom: } \\
\text { Decision-making rights of participants }\end{array}$ & $\begin{array}{l}\text { Responsibility: } \\
\text { Performance evaluation and incentives }\end{array}$ \\
\hline Users & $\begin{array}{l}\text { Choice of supplier: } \\
\text { - Where: inside or outside the } \\
\text { organization } \\
\text { - By whom: the users, a representative, a } \\
\text { gatekeeper }\end{array}$ & $\begin{array}{l}\text { Opportunity costs: } \\
\text { - Shadow invoice } \\
\text { - Voucher } \\
\text { - Price } \\
\text { - Co-payment }\end{array}$ \\
\hline Suppliers & $\begin{array}{l}\text { Discretion for: } \\
\text { - Organizing the activity } \\
\text { - Transacting internally } \\
\text { - Transacting externally }\end{array}$ & $\begin{array}{l}\text { Divisionalization: } \\
\text { - } \begin{array}{l}\text { Responsibility centers (for profit, cost, } \\
\text { investment) }\end{array} \\
\text { - } \begin{array}{l}\text { Franchised administration (units' } \\
\text { managers hold property rights, hire } \\
\text { employees and are paid with the unit’s } \\
\text { profit) }\end{array} \\
\text { Individual compensation function: } \\
\text { - Pay for performance } \\
\text { - Professional career } \\
\text { - Units' profits (in franchised } \\
\text { administration) }\end{array}$ \\
\hline
\end{tabular}


The existence of such horizontal control does not make vertical control less necessary, however, but it does transform its nature: it must ensure that mutual control between users and suppliers functions correctly so that they do not behave selfishly and their interaction is socially beneficial. The agency responsible for both users and suppliers must preclude that they use their freedom to serve only their own goals, sacrificing the common interest. Given that users and suppliers now enjoy more discretion and stronger incentives, vertical control must, in fact, be more effective (Milgrom and Roberts 1992:226-28).

Ideally, reform will re-create market functioning (which is why people often talk about “internal markets”[Enthoven 1991]), so will introduce competition, both among suppliers and among the ways in which users might allocate their resources. It might even go so far as to change the nature of the supplying unit, converting it into a profit center or even a franchise. However, such a radical solution usually requires considerable investments and expenditure for planning and managing the whole process (Arruñada and Hansen 2015). Its effectiveness, therefore, is doubtful. In fact, in order to supervise the reform and manage the internal market, a giant planning apparatus is often set up, a "Gosplan” which, in turn, has all the characteristics and defects of an expense centre (Arruñada 1997). An internal market is only a market in name, as there are no property rights and all prices are administered (Hayek 1945).

\section{The organization of privately valuable services in the liberal state}

An alternative, seemingly more modest, solution is to apply just some market mechanisms, or just in some dimensions, but more forcefully. The patterns followed by the 
traditional organization of public services in the liberal state were often of this type, combining partial discretion by decision makers (limited, e.g., to certain dimensions such as the choice of supplier by the user or the tenure-based choice of specific jobs by professional civil servants) with powerful incentives (based, e.g., on user fees and pay for performance, a solution commonly found in the organization of notaries, registrars, judicial clerks or family doctors).

In order to illustrate the arguments, I now review three solutions adopted in the $19^{\text {th }}$ century for judicial and quasi-judicial services in the Spanish Public Administration: notaries, registries and courts. These solutions differ drastically from both standard expense centers and internal markets. In contrast to the standard expense center, services are financed with user fees and at least some key suppliers are paid for performance. In contrast with the internal market, incentives are much stronger, as users pay real money and suppliers are paid real bonuses. However, they are characterized by the limited size of the planning or supervisory agency. Instead of aiming for a complete artificial market, too costly to achieve, these admittedly suboptimal—in Simon’s (1956) terms “satisficing”—solutions seem to provide a better alignment of a few key dimensions of participants' behavior. ${ }^{4}$

Strong user fees. Court users paid fees which financed a substantial proportion of costs. Elimination of these judicial rates in 1986 put an end to this system. This resulted in congestion, rationing, frivolous litigation, capacity increases and greater delays in civil than in criminal cases (Pastor, 1993). User fees were reintroduced for commercial cases in 2002 and generalized in 2012 (Gómez, Celentani and Ganuza 2012). In contrast, both notaries and registrars are paid explicit, regulated fees by one of the parties, and these fees finance 
services fully. Both notaries and registrars have shown considerable flexibility in adapting to drastic swings in market demand, caused by the real estate bubble in the period 2000-2007 and the adaptation of corporation law a decade earlier. In contrast, Spanish civil registries, land cadastres, which are organized as, respectively, expense and revenue centers, perform appallingly in terms of delays and adaptation to demand changes.

Limited user choice. Free choice of supplier is allowed only for essentially private services such as notaries’ services (Arruñada 1996), but not for registries and courts. Since the notary mainly serves the parties to the contract, it makes sense for them to freely choose the notary. It is also understandable that notaries tend to be flexible regarding the wishes of the parties, interpreting legal restrictions in the way that best suits them. Conversely, for courts and registries, freedom of choice would endanger their impartiality and their basic function of protecting third parties: e.g., free choice of land registry would not protect parties such as future land purchasers, who are unknown at the time of choosing (Arruñada 2003).

Strong incentives to suppliers. Incentives to notaries and registrars are as strong as they can be, as both notary’s offices and registers function as public franchisees. Each notary and each registrar is responsible for one office, hires their own employees and resources, and is paid (together with top employees) with the residual profit of the office, after the less professional staff and after any office costs have been paid. Conversely, judges are paid a fixed salary with substantial increases linked to tenure and promotion, a typical characteristic of judicial careers (Posner 1995). However, in a system that remained in place in many courts until the 1980s, though it was being phased-out since 1947, courts’ clerks were paid

4 Arruñada and Hansen (2015) compare several of these solutions in greater depth. 
substantial bonuses linked to processed cases. ${ }^{5}$ This motivated paperwork productivity without damaging the quality of court decisions. Court clerks controlled judges' productivity because, if the latter did not deal with cases expeditiously, they did not receive the full variable remuneration; and judges (who were often worse paid than the clerks so felt a degree of rivalry that was not always negative) controlled the quality of the office's administrative work which, since it tended to be done fast, was not always as it should be. In all cases, the key elements of quality control were the deferred nature of remuneration and personal liability in professional decisions. This latter aspect is specially important for registrars, who are subject to a standard of strict (i.e., non-negligent) liability.

Role of automatic control. Instead of specialized control by a supervisory bureaucracy, incentives are arranged in a way that favors mutual control by participants. Not only users control suppliers and suppliers control users but complementary suppliers control each other (e.g., registries control notaries, and vice versa, and, similarly, court clerks and judges control each other). Such controls between complementary suppliers are enhanced by using different compensation functions. For instance, both notaries and registrars are paid with net user fees; however, notaries are chosen by users and compete with each other while registrars enjoy territorial monopolies. Consequently, notaries strive to satisfy their clients while registrars strive for legal quality and the protection of third parties different from notaries' clients. Similarly, court clerks were paid a variable fee for performance, motivating them to speed up case paperwork while judges were paid a fixed salary and worried about possible appeals that might damage their reputation and chances of promotion. In both cases, opposite

5 In 2004, to deal with court congestion, the Government introduced short-term performance targets, which caused an increase in average measured productivity and reduced 
compensation functions create tension between complementary suppliers, providing some degree of automatic control as well as two sources of competitive information for regulators. A similar formula was used in the regulation, administrative appeal and inspection of notary's offices and registries by concentrating these supervisory tasks in the hands of a tiny and specialized body of civil servants at the General Directorate for Registries and Notarial Offices. These civil servants were paid a fixed salary below the variable compensation of the notaries and registrars they were inspecting, so they tended to be stern about any slackness.

\section{Options for the organization of public registries}

\subsection{Traditional organization of public registries}

Interestingly, the traditional organization of many public registries partly relies on some of these patterns, which sets them apart from the standard bureaucratic arrangements of expense centers that are characteristic of public administration. For registries, it has been common to rely on more independent agencies, which are not financed with taxes but with user fees, treating them as revenue centers; and to pay at least the key professional workersthe registrars—according to performance. ${ }^{6}$

For example, in England, the Land Registry was organized as a nonministerial government department in 1862, as an executive agency in 1990, and as a trading fund in

the productivity of top performing judges (Bagues and Esteve-Volart 2010). They were opposed by judges' associations and may have damaged professional morale. 
1993. The 1990 reform reduced average processing times from 34 weeks to eight days, even though it did not always avoid registration delays; and, since 2003, its objective has been to achieve a minimum 3.5 percent return on average capital employed. It is staffed by civil servants but has its own pay bargaining and pay and grading structures, suited to its requirements. Since 2009, different British governments have even considered privatization as a possibility for future organization. Similarly, Companies House is organized as an executive agency with trading fund status and, as such, is subject to business-like organizational patterns, including also a 3.5 percent return on capital and performance pay. As such trading funds, they have standing authority under the Government Trading Funds 1973 Act to use their receipts to meet their expenditures.

In France, the land registry is also financed with user fees and run by the conservateurs d'hypothèques who, though civil servants, used to enjoy a special status with variable compensation, substantial deferred compensation in the form of pensions, and personal liability for registration errors, as in Luxembourg. Likewise, the greffiers du Tribunal de Commerce who maintain the French company registry are public officers endowed with public authority and also liberal professionals and, as such, are compensated with the net revenue of the registries.

As mentioned above, a similar solution is applied in Spain where both land and company registries are run by registrars who are civil servants (registradores). A government department regulates entry, procedures, and prices. But each registrar manages a registry office, bears its costs, and earns its residual profit. In particular, each registrar recruits the

6 This section borrows from Arruñada (2102:217-20), omitting most references. 
office employees, who are not civil servants and some of whom are typically paid with a share of the office's profits.

Stronger incentives have also been introduced in registries in many countries such as, for instance, the Netherlands in 1994. Other jurisdictions, such as New Brunswick, have relied on state-owned companies, and others on specific public-private partnerships.

Furthermore, registries' incentives are often strong in other dimensions. Thus, it is common for user fees to be so high that registries are not only self-financed but also become cash cows-i.e., important sources of revenue for governments. Individual providers are also subject to strong incentives, especially in countries where registrars, despite being civil servants, are compensated with the net revenue of the office, after hiring and paying for all other resources. In contrast, titling efforts in developing countries have often deviated from these patterns, charging users a small fee or none at all for service and paying fixed salaries to providers. Unsurprisingly, they tend to suffer the common problems of discretionary expense centers: excessive size, unsatisfied demand, low productivity, and budgetary crisis.

In line with these strong incentives of some registries, both users and providers are subject to administrative constraints and economic incentives designed to provide automatic control. Thus, users are not free to choose providers, and providers must follow a detailed set of procedures, which substantially limits their discretion. This arrangement is broadly similar to the one found in privately organized franchising networks, in which the discretion of franchisees is constrained in order to produce a homogenous service across the whole network but at the same time they are strongly motivated to make efficient use of local resources (Rubin 1978, and Blair and Lafontaine 2005). It makes sense in registries, given that their outputs are the inputs of further judicial and contractual processes, which makes standardization of quality a key attribute. 
In addition, economic incentives are adapted in several ways to automatically control service quality. First, subsequent providers are often subject to contrary incentives, creating a system of checks and balances. Registries are monopolies and users cannot choose between registrars, who are thus placed in an independent position, suitable to protect the interest of third parties. Yet, conveyancers are in competition and clients are free to choose among conveyancers, who are encouraged to place the interests of their clients before those of third parties. Understandably, these contrary incentives cause a productive structural tension between registries and conveyancers. Similarly, when registrars are subject to strong performance incentives, their regulators and supervisors (including judges) tend to be paid fixed salaries, a difference that also generates opposing views and fruitful tensions between registrars and their controllers.

Second, some quality attributes, such as service time and even legal quality, are often internalized by specific incentives. For example, providing speedy service is motivated by making fees collectible only after the service is completed. Following this pattern, users of registries of rights pay lodgment fees after applying for registration but only pay registration fees after registration, thus reducing the perennial tendency of these registries to delay registration decisions. Postponing payment in this way seems to provide weaker incentives than urgency surcharges, but it is also less prone to abuse (e.g., urgency surcharges encourage the registry to delay its standard processing).

On the other hand, the legal quality of registration decisions is automatically controlled by subjecting registrars to strict, instead of negligent, liability. This method ensures law enforcement by the registry, which risks causing a backlash against the registry when the law itself is inefficiently mandatory. Moreover, repeated observations suggest that personal liability is also hardly viable unless registrars are paid as liberal professionals. In Italy, strict 
liability was transformed into a weaker, negligence-based regime ten years after suppressing residual compensation. In Puerto Rico in 1914, the inability of registrars to indemnify parties damaged by registration failure put an end to residual compensation; since then, the registry has suffered considerable delays. In France, the 2013 reform simultaneously transferred to the state the civil liability previously borne by individual registrars and modified their compensation, from a variable amount linked to volume to a fixed salary.

All these characteristics—administratively regulated procedures, strong legal effects, fees for service, compensation with a residual profit, strict personal liability, and organizing providers as State franchisees — constitute a hybrid organizational form between public administration and private provision of registry services. This hybrid nature is probably more effective, sustainable, and flexible than the more extreme solutions in which registries are either purely private or part of standard public administration. Private registries may enjoy stronger incentives but lack public effects (remember the US cases of title plants operated by title insurance companies as well as that of the Mortgage Electronic Registration System). And public registries have stronger effects but weaker incentives, especially when organized as standard public agencies, which often causes substandard performance or, in the case of registries of rights, mortally debilitates them. The solution seems to lie in hybrid organizational forms, which can produce public effects while keeping strong incentives for performance. 


\subsection{Privatization efforts}

Several states in Canada and Australia, as well as the government of the United Kingdom, have recently privatized or made plans to privatize their land registries. ${ }^{7}$ These privatizations are grounded on a long term contract or lease by which the state subcontracts the provision of registration services to a firm which, depending on the specific case, is at least partly owned by private investors. This contract establishes rights, duties and standards, including payments (both an initial lump sum and annual royalties often based on transaction volumes), with data ownership and regulatory powers remaining with the government.

In most cases, the government contracts out what previously was organized as an expense or revenue center within the government bureaucracy. In contrast, the Saskatchewan province of Canada started by first creating a Crown-owned corporation, which 13 years later sold shares to the public. The proposal in 2016 by the UK Government for the Land Register of England and Wales was partly similar, as between 1990 and 1993 it had been transformed from an expense center (a non-ministerial government department with no specific financial targets) into a sort of state-owned firm with an objective to return 3.5\% on average capital employed, the return being the difference between user fees generated net of expenses (Arruñada and Hansen, 2015).

The organization of privatized registries shares some of its main features with franchised solutions and others with state-owned firms (which are closer to the "internal market" solution). They are similar to franchised registries in that the profit is appropriated by the

7 See Thomas, Griggs and Low (2018). The UK Government also ran a public consultation on moving Land Registry operations to the private sector though a contract between the 
service provider, while in a state-owned firm it is appropriated by the state. (For example, any surplus generated by the English Land Registry remains in a separate account at the Bank of England, which can be drawn on to cover losses in years with few property transactions). However, they are similar to state-owned firms in that professionals (mainly, registrars) are not paid with a profit but with a salary and (at most) a bonus based on an artificial indicator of individual performance. Moreover, liability for registration errors is borne by the firm and the state, while in the franchised solution it is borne by individual registrars themselves, often in terms of strict liability.

These differences hold consequences for both the strength and the organization of incentives. Incentives are understandably weaker when profits are retained by the state. First, from the registrar perspective, they are much stronger in a franchised organization, as registrars are compensated with the profit of the particular registry office that they are in charge of. Second, with respect to planning and management, given the lack of individualized profits and liability, both state-owned and private firms need to spend more on creating and running an artificial incentive structure for registrars.

In any case, the nature of registries makes it necessary for them to be monopolies: they must be neutral not only between contracting parties but also with respect to strangers to the contract. Consequently, contracting parties cannot be free to choose register and registrar. This makes privatization harder because, to avoid abuses, a privatized register needs to be tightly regulated. Given that privatization introduces stronger incentives, the necessary regulation may even need to be tighter than under alternative systems in which incentives are weaker.

government and a private operator, but finally decided against it because of substantial 
Moreover, offering powerful incentives to registrars is more important in registration systems in which their role has a more professional content and is more discretionary, less automatic. The main differences in this regard lie in the type of registry-recordation versus registration—and, for registration, in the type of technique being used.

First, registries acting as pure recorders of deeds, which mostly perform ministerial duties consisting of the simpler administrative tasks of dating and filing lodged documents, as well as issuing copies and certificates, are damaged less if organized as standard bureaucracies. However, even for them, it is necessary to ensure speedy processing and preclude corruption, so they perform better when bureaucrats are paid for performance and with deferred compensation. Conversely, given that registries of rights must make sure that filings respect third parties' property rights and conform to law before they are accepted for registration, their performance crucially depends on the application of legal knowledge by competent registrars. Unsurprisingly, successful registries of rights tend to adopt some of the features of law firms. Registrars’ competence must be at least comparable to that of the conveyancers who prepare the filings that registrars have to examine. Therefore, registries must pay registrars competitive salaries to recruit and retain competent lawyers. Registrars must also play a key role in organizing all other resources, as their contribution defines the performance of the whole registry. Given the importance of their registration decisions, the organization of registries of rights tends to be focused on supporting them by subordinating other resources that take care of administrative tasks and routine checks. Variable compensation provides a direct link between pay and performance, even though it requires additional mechanisms such

opposition (UK Parliament, 2016). 
as stricter personal liability. Moreover, rising compensation based on seniority helps parallel the accumulation of human capital and the consequent increase in outside opportunities.

Second, also important is the scope of the numerus clausus of property rights and the subsequent registration technique. In particular, the role of automatic processes should in principle be greater in registration systems with a stricter numerus clausus plus clear application of the abstraction principle, as in Germany. Conversely, it should be smaller in countries such as Austria, Spain or Switzerland, especially when register entries summarize the essentials of transactions, instead of merely indexing the in rem dimensions.

\section{Concluding remarks}

This article compares five ways of organizing the provision of privately valuable public services: budgetary bureaucracy based on expense centers, comprehensive internal markets, including revenue centers, traditional hybrid solutions with franchised units, and privatized public services. These hybrid solutions, which have survived for many decades producing relatively effective outcomes, contrast starkly not only with those of standard bureaucracy but also with those found in modern internal markets and privatized services. Whereas internal markets strive to develop comprehensive measures of performance but provide weak incentives, these liberal-state solutions rely on partial measures of performance but provide strong incentives. Moreover, in contrast with privatized services, these incentives operate at the level of the individual professional in charge of the service. Also, instead of requiring large staffs to manage suppliers and their interaction with users in the internal market, such 
hybrid solutions work in a regime of "automatic management” and are therefore frugal in their use of planning and supervision resources.

\section{7. $\quad$ References}

Arrow, K. J. (1964), “Control in Large Organizations,” Management Science, 10(3), 397408.

Arruñada, B. (1996), “The Economics of Notaries,” European Journal of Law and Economics, 3(1), 5-37.

Arruñada, B. (1997), "Internal Markets in the Reform of the Spanish NHS: A Comment on the Planners’ Latest Fantasy,” in J. G. Backhaus, (ed.), Essays in Social Security and Taxation, Metropolis, Marburg, 429-44.

Arruñada, B. (2003), “Property Enforcement as Organized Consent,” Journal of Law, Economics, and Organization, 19(2), 401-44

Arruñada, B. (2012), Institutional Foundations of Impersonal Exchange: The Theory and Policy of Contractual Registries, University of Chicago Press, Chicago.

Arruñada, B., and S. Hansen (2015), “Organizing Public Good Provision: Lessons from Managerial Accounting,” International Review of Law and Economics, 42, 185-91.

Bagues, M., and B. Esteve-Volart (2010), "Performance Pay and Judicial Production: Evidence from Spain,” Working Paper, June (http://www.manuelbagues.com/bagues\%20\&\%20esteve-volart\%20-\%20judges.pdf, visited March 13, 2013).

Blair, R. D., and F. Lafontaine (2005), The Economics of Franchising, Cambridge University Press, Cambridge.

Breton, A. (1974), An Economic Theory of Representative Government, Aldine, Chicago.

Dunleavy, P. (1985), "Bureaucrats, Budgets and the Growth of the State,” British Journal of Political Science, 15, 299-328.

Dunleavy, P. (1991), Democracy, Bureaucracy and Public Choice, Harvester Wheatsheaf, Brighton.

Enthoven, A. C. (1991), “Internal Market Reform of the British National Health Service,” Health Affairs 10(3), 60-70.

Gómez, F., M. Celentani and J.J. Ganuza (2012), “A vueltas con las tasas judiciales,” Nada es gratis, December 18 (http://www.fedeablogs.net/economia/?p=26980, visited March 13, 2013).

Hayek, F.A. (1945), “The Use of Knowledge in Society,” American Economic Review, 35(4), 519-30. 
Jensen, M. C., and W. H. Meckling (1995), “Specific and General Knowledge, and Organizational Structure,” Journal of Applied Corporate Finance, 8(2), 4-18.

Kaplan, R. S., and A. A. Atkinson (1989), Advanced Management Accounting, $2^{\text {nd }}$ ed., Prentice-Hall, Englewood Cliffs, NJ.

Milgrom, P., and J. Roberts (1992), Economics, Organization and Management, PrenticeHall, Englewood Cliffs, NJ.

Neuman, J. L. (1975), “Make Overhead Cuts that Last,” Harvard Business Review, MayJune, 116-26.

Niskanen, W. A. (1968), "Nonmarket Decision Making: The Peculiar Economics of Bureaucracy,” American Economic Review, 58(1), 293-305.

Niskanen, W. A. (1971), Bureaucracy and Representative Government, Aldine Atherton, Chicago.

Pastor Prieto, S. (1993), ¡Ah de la justicia! Política judicial y economía, Madrid, Cívitas.

Peacock, A. T. (1983), "Public X-Inefficiency: Informational and Institutional Constraints," in H. Hanusch, (ed.), Anatomy of Government Deficiencies, Springer, Berlin, 125-37.

Peters, B. G. (1996), The Future of Governing: Four Emerging Models, University Press of Kansas, Lawrence.

Posner, R. A. (1995), "What Do Judges Maximize”, in Overcoming Law, Harvard University Press, Cambridge, MA, 109-44.

Rubin, P. H. (1978), “The Theory of the Firm and the Structure of the Franchise Contract." Journal of Law and Economics, 21, 223- 33.

Simon, H. A. (1956), "Rational Choice and the Structure of the Environment," Psychological Review, 63(2), 129-38.

Thomas, Rod, Lynden Griggs and Rouhshi Low (2018), “The Privatisation of RegistersRecent Developments and Thoughts from a Torrens Perspective,” Working Paper.

UK Parliament, 2016, “Land Registry Privatisation”, December 9, http://researchbriefings.parliament.uk/ResearchBriefing/Summary/CBP-7556\#fullreport, accessed May 26, 2018.

Zimmerman, J. L. (1979), “The Costs and Benefits of Cost Allocations,” Accounting Review, 54(3), 504-21. 